\title{
The Influence of Financial Attitude, Financial Literacy, and Locus of Control on Financial Management Behavior
}

\author{
Stella Maris Juhar Baptista ${ }^{1 *}$, Andrieta Shintia Dewi ${ }^{2}$ \\ 1,2 Telkom University, Bandung, West Java, Indonesia
}

\section{A R T I C L E I N F O}

Article history:

Received 03 January 2021

Received in revised form

23 January 2021

Accepted 18 February 2021

Available online 25

February 2021

Keywords:

Financial Management

Behavior, Consumptive

Behavior

\begin{abstract}
A B S T R A C T
The financial attitude possessed by individuals can be realized because of literacy or knowledge. Meanwhile, the current level of workingage literacy in Semarang City needs to be improved. This background can be seen in the widespread use of credit cards, excessive consumption activities, and the low level of public knowledge about financial institutions and financial products and services. To inhibit this desire, a high locus of control is needed in the individual. This study aims to analyze the influence and relationship between financial attitudes, financial literacy, and locus of control on financial management behavior at working-age in Semarang City. The research method used is the quantitative method with multiple regression analysis. The data collection technique was by distributing questionnaires to four hundred productive age groups in the city of Semarang. The results of this study showed that there was an influence between financial attitudes and financial literacy on partial financial behavior management based on hypothesis testing (t-test), but there is no influence between the locus of control on financial management behavior partially.
\end{abstract}

\section{Introduction}

Lack of saving, investing, emergency fund planning, and budgeting activities funds for the future will arise when people's financial behavior in Indonesia tends to be consumptive because it is not responsible financial management behavior (Herdjiono \& Damanik, 2016). Technological developments bring about many changes in patterns and lifestyles (Ida et al., 2020). The result of Otoritas Jasa Keuangan (OJK) survey in 2016 , only $29.66 \%$ of the population that has knowledge, skill, creditability, attitude, and behavior that sufficient in use finance product and service, it is mean at this moment there are many people still need to give a financial education so that can minimalize the risk of a financial problem (Pradiningtyas \& Lukiastuti, 2019).

Financial attitude is the application of principles finance to create and maintain value through creating resource decisions and management the best (Khairani \& Alfarisi, 2019). Personal financial behavior individual is determined by his financial attitude (Djou, 2019). Financial attitude is defined as the state of mind, opinion, and judgment about his finances applied to attitude (Humaira \& Sagoro, 2018). The indicator of financial attitude a good and responsibility on each individual can be observed from his attitude on organizing in and out cash flow, investment or for long-term, and can handle the financial suitable for his needs (Budiono, 2020). It is a wasteful and consumptive attitude a phenomenon that often occurs among productive age, including students (Andansari, 2018). Students as the millennial generation is a component of that society the amount is quite large and as an agent of change also plays a role in bringing change in all areas including in economic terms (Asih \& Khafid, 2020).

Financial literacy is a person's activity in increasing knowledge as well skills in the field of finance (Setyawan \& Wulandari, 2020). Low financial literacy will have an impact on low desire to save up for planning on future spending habits excessive will make people consumptive so it is difficult to be a smart consumer (Putri et al., 2016). The background of the low level of financial literacy is that the financial industry is increasingly complex and on average fewer people can face these changes (Ningtyas, 2019). Understanding financial literacy important, especially for generations Millennials are known to be consumptive and lack financial management the good one (Qurotaa'yun \& Krisnawati, 2019). The rate of 
financial literacy in Central Java in 2016 (Otoritas Jasa Keuangan, 2016), aggregate 33.51\% and passed increase to $47.83 \%$ in 2019 (Otoritas Jasa Keuangan, 2019). The increasing of financial literacy show there is increasing of financial insight in society and society access to financial product and service (Tempo.co, 2019). However, in 2016 the number of credit card transactions and credit cards in circulation in Indonesia increased until 2019 (Bank Indonesia, 2020). Thus, the people of Semarang City who are credit card users at Semarang Mall have a reason that using a credit card when shopping is easy, practical, and sometimes gets a discount when making transactions (Wibowo \& Athanasius, 2019). Credit card users at Semarang Mall are mostly women aged 39-49 years who work as entrepreneurs by making transactions using credit cards as much as $1-3 \mathrm{x}$ even 10 times in the last month. Financial literacy consists of some abilities and knowledge of finances owned by someone to be able to manage or use some money to improve his standard of living (Rumbianingrum \& Wijangka, 2018).

Self-control is an individual skill insensitivity to read the situation themselves and their environment (Udayanthi et al., 2018). Locus of control operated as an internal and external construct that measures someone's belief in the events that happened to his life, the act of the individual will make an appearance the desired result internal locus of control or actions taken by an outside individual such as ability or strength in the results the desired end it will occur external locus of control (Muhidia, 2019). There is a difference in the characteristics of the two types, namely: locus of internal control for example have the initiative or high creativity and think effectively, then the external locus of control includes lack of initiative or creativity, and always think if there is a correlation between effort and success and lack in information search (Saepuloh \& Sukaris, 2019). While financial control is an activity evaluate whether financial management is by what was planned or budgeted for (Wicaksono \& Nuryana, 2020). The locus of control owned by each individual is different from one individual to another (Hidayah \& Bowo, 2018). Despite a large number of credit card users and transactions at Semarang Mall, the locus of control owned by private university economic students accredited B in Semarang is in the high category, so they can control any form of expenditure that is deemed unimportant and damages financial management which has been determined (Pradiningtyas \& Lukiastuti, 2019).

Individuals who can apply a good lifestyle will have good financial management behavior (Shinta \& Lestari, 2019). Financial management so that there is a balance between income and expenditure (Rizkiawati \& Asandimitra, 2018). Behavioral finance is one of the most important parts of individual finance both for the term short and long term (Wijaya \& Yanuar, 2021). The City Minimum Wage (UMK) of IDR 2,175,000 makes Semarang City at the highest level of UMK in Central Java in 2020. Meanwhile, if we look at the data every year, the consumer price index in Semarang as of December has increased, which means that the purchase of supplies and the inflation rate in Semarang is getting faster (UGM, 2017). Such as a survey conducted by (Susiana, 2018) in the Tambaklorok community, Semarang City, that the people there work as civil servants, fish processors, and fishermen who are included in the category of people who have impulsive consumptive behavior, namely purchasing products and services that are useful for individuals and without planning. Financial management behavior is associated with individual responsibility in managing finance (Suwatno et al., 2019). Responsibility financial responsibility is a management process of money and other assets in a way that is considered productive (Mardahleni, 2020).

Mien \& Thao (2015) suggest that financial attitudes and financial literacy or financial knowledge are significantly positively related to personal financial management behavior, while someone who has a locus of control is less likely to behave badly in personal financial management. Research conducted by Financial knowledge, financial attitude, and locus of control of creative economy actors in the fashion subsector in Kediri City had a significant influence on financial management behaviour (Mardhatillah et al., 2020). Research conducted by Bapat (2020) obtained findings that validated that there was an influence on the relationship between financial attitudes, financial literacy, and locus of control (internal) with financial management behavior in young adults. Previous research suggested that financial attitudes, financial literacy, and locus of control have a positive and significant effect on financial management behaviour. Thus, this study aims to analyze whether financial attitudes, financial literacy, and locus of control have a partial and simultaneous influence on financial management behavior at productive age in Semarang City.

\section{Methods}

Based on the research of Mien and Thao (2015) obtained a framework where financial attitude, financial literacy, and locus of control influencing financial management behavior. A characteristic of the sample is working-age in Semarang City. This research use Slovin's formula for determined the sample. 
Based on the result of sample calculation use Slovin's formula, can be known if the minimal quantity sample in this research is 399.85 to simplified so the number we round to 400 . Data analysis technique in this research using multiple linear regression there is:

$Y=a+b_{1} X_{1}+b_{2} X_{2}+b_{3} X_{3}$

Explanation:

$\mathrm{Y}=$ Financial Management Behavior

$\mathrm{a}=$ Constant

$\mathrm{b}=$ Coefficient Regression (increase and decrease score)

$X_{1}=$ Financial Attitude

$X_{2}=$ Financial Literacy

$X_{a}=$ Locus of Control.

\section{Results and Discussions}

\section{Results}

\section{Multiple Linear Regression Analysis}

Based on the multiple linear regression analysis results, the equation is:

$Y=14.012+0.802 X_{1}+0.359 X_{2}+0.094 X_{a}$

It can be seen that the constant value of the equation above is 16,563 , this figure shows that the dependent variable (Financial Management Behavior (Y)) is not influenced by independent variables (Financial Attitudes (X1), Financial Literacy (X2), and Locus of Control (X3)), then the average value for the dependent variable (Financial Management Behavior (Y)) is 16,563.

The variable X1, namely Financial Attitudes, has a positive regression coefficient value of 0.802 . This shows that there is a direct relationship between financial attitudes and financial management behavior. Every time there is an increase in financial attitudes, the behavior of financial management will increase by 0.802 . The variable X2, namely Financial Literacy, has a positive regression coefficient value of 0.359 . This shows that there is a direct relationship between financial literacy and financial management behavior. Every time there is an increase in financial literacy, the behavior of financial management will increase by 0.359 .

The X3 variable, namely Locus of Control, has a positive regression coefficient value of 0.094 . This indicates that there is a unidirectional relationship between locus of control and financial management behavior. Every time there is an increase in the locus of control, the financial management behavior will increase by 0.094 .

\section{F Test}

Based on the data processing result in Table 2 can be known if the $\mathrm{F}_{\text {count }}$ score is 76.243. Hypothesis test by $\mathrm{F}$ test can also be known by comparing significant score. From Table 1 is known if significant score 0.0000 , so the significant score $(0.000)<0.05$. This shows that $\mathrm{H}_{0}$ ignored and $\mathrm{H}_{4}$ received, which means there is a simultaneous effect between financial attitude, financial literacy, and locus of control on financial management behavior.

\section{Financial Attitude to Financial Management Behavior}

To know where the hypothesis will receive the variable partially, so needed table. In determined $t_{\text {tabel, }}$ can use $\frac{\pi}{2}=\frac{0.05}{2}=0.025$, and df from $n-(k+1)=396$, so that get $t_{\text {table }}$ is 1.966 . The financial attitude variable has $\mathrm{t}_{\text {count }}(10.024)>\mathrm{t}_{\text {table }}(1.966)$ or significant score $(0.000)<0.05$, so $\mathrm{H}_{0}$ ignored and $\mathrm{H}_{1}$ received, it is mean there is a partial effect between financial attitude on financial management behavior. This research is the same as the research that has been done by Mien \& Thao (2015) and Herdjiono \& Damanik (2016).

\section{Financial Literacy to Financial Management Behavior}

The financial literacy variable has $t_{\text {count }}(5.052)>t_{\text {table }}(1.966)$ or significant score $(0.000)>0.05$, so $\mathrm{H}_{0}$ ignored and $\mathrm{H}_{2}$ received, it is mean there is a partial effect between financial literacy on financial management behavior. This research is the same as the research that has been done by Adiputra \& Patricia (2020) and Mardhatillah et al. (2020). 


\section{Locus of Control to Financial Management Behavior}

Locus of control variable has $t_{\text {count }}(0.934) \leq(1.966)$ or significant score $(0.351)>0.05$, so $\mathrm{H}_{0}$ received and $\mathrm{H}_{3}$ ignored, it is mean there is not partially effect between locus of control on financial management behavior. This research is the same as the research that has been done by Bapat (2020) and Pradiningtyas \& Lukiastuti (2019).

\section{Determination Coefficient}

From the calculation result in Table 4 is known that the determination coefficient score is $34.5 \%$. This shows if financial attitude, financial literacy, and locus of control influence financial management behavior by $36.6 \%$.

\section{Discussion}

Based on the results of multiple linear regression analysis, it is known that financial attitudes have a positive influence on financial management behavior. In this research, financial attitude belongs in the very good category. In this study, it was found that the people of productive age in Semarang City believe that planning for the future is the best way to move forward as much as $91.75 \%$.

Next, same as financial attitude, financial literacy also has a positive effect on financial management behavior. In this research is known if financial literacy owned by the respondent belongs in a good category and as described by Otoritas Jasa Keuangan (OJK) if the level of financial literacy in Central Java is $47.38 \%$. The individual who has well financial literacy can organize his finances and planning the future, and smarter in choosing and giving complaints about product and service which their consumption. In this study, it was found that the productive age community of Semarang City knew about managing personal finances as much as $85 \%$.

Financial literacy is a person's activity in increasing knowledge as well skills in the field of finance (Setyawan \& Wulandari, 2020). Low financial literacy will have an impact on low desire to save up for planning on future spending habits excessive will make people consumptive so it is difficult to be a smart consumer (Putri et al., 2016). The background of the low level of financial literacy is that the financial industry is increasingly complex and on average fewer people can face these changes (Ningtyas, 2019). Understanding financial literacy important, especially for generations Millennials are known to be consumptive and lack financial management the good one (Qurotaa'yun \& Krisnawati, 2019). The rate of financial literacy in Central Java in 2016 (Otoritas Jasa Keuangan, 2016), aggregate 33.51\% and passed increase to $47.83 \%$ in 2019 (Otoritas Jasa Keuangan, 2019). The increasing of financial literacy show there is increasing of financial insight in society and society access to financial product and service (Tempo.co, 2019). However, in 2016 the number of credit card transactions and credit cards in circulation in Indonesia increased until 2019 (Bank Indonesia, 2020). Thus, the people of Semarang City who are credit card users at Semarang Mall have a reason that using a credit card when shopping is easy, practical, and sometimes gets a discount when making transactions (Wibowo \& Athanasius, 2019). Credit card users at Semarang Mall are mostly women aged 39-49 years who work as entrepreneurs by making transactions using credit cards as much as 1-3x even 10 times in the last month. Financial literacy consists of some abilities and knowledge of finances owned by someone to be able to manage or use some money to improve his standard of living (Rumbianingrum \& Wijangka, 2018).

In this study, it was found that the people of productive age in Semarang City believe that what happens to them in the future depends on them as much as $91.1 \%$. In this study, the locus of control which is owned by the respondent tends to be neutral because if the locus of control variable is combined with the variables of financial attitudes and financial literacy, it will have little effect on financial management behavior. So that if an individual only has a locus of control without financial attitudes and financial literacy in his life, then the locus of control will not have an effect that results in the absence of the ability to control their finances. Locus of control which is owned by individuals refers to the extent to which the individual can control any events that affect them. The results of this study are in line with research conducted by Bapat (2020) and Pradiningtyas \& Lukiastuti (2019).

Through the simultaneous hypothesis test ( $\mathrm{F}$ test) has a goal to find out whether all the independent variables in this research are financial attitude, financial literacy, and locus of control entered into the model has a joint influence on the dependent variable in this research is financial management behavior. Known there are simultaneously effect between financial attitude, financial literacy, and locus of control on financial management behavior is $36.6 \%$, while the other $64.4 \%$ is influenced by other variables that not researching in this research. But the t test results show that there is no partial influence between locus of control and financial management behavior. This means that the level of locus of control or self-control that is owned by a person does not affect if it is not accompanied by other factors or variables. 


\section{Conclusion}

Based on the results of research and data processing, it is found that financial attitudes have a significant effect on financial management behavior on working age in Semarang City. This means that people know about how they behave towards their finances, such as planning for the future, saving money, and other financial planning. Then financial literacy also has a significant influence on financial management behavior. This means that people have knowledge about finances and account balances in their accounts so that they can manage their finances. However, locus of control does not have a partially significant effect on financial management behavior because the locus of control cannot affect individuals without other variables or factors such as financial attitudes and financial literacy. This shows that the locus of control in society will not appear if there are no other variables that simultaneously influence them, for example, people can change important things in their lives if the factors of financial attitudes and financial literacy simultaneously affect them. Thus, financial attitudes, financial literacy, and locus of control simultaneously have a significant effect on working age in the city of Semarang.

\section{References}

Adiputra, I. G., \& Patricia, E. (2020). The Effect of Financial Attitude, Financial Knowledge, and Income on Financial Management Behavior. Advances in Social Science, Education and Humanities Research, 439. https://doi.org/10.2991/assehr.k.200515.019.

Andansari, P. I. (2018). Pengaruh Financial Attitude Dan Lingkungan Sosial Terhadap Literasi Keuangan Mahasiswa. Ecodunamika: Jurnal Pendidikan Ekonomi, 1(1), 1-7. https://ejournal.uksw.edu/ecodunamika/article/view/1519.

Asih, S. W., \& Khafid, M. (2020). Pengaruh Financial Knowledge, Financial Attitude dan Income Terhadap Personal Financial Management Behavior melalui Locus Of Control sebagai Variabel Intervening. Economic Education Analysis Journal, 9(3), 748-767. https://doi.org/10.15294/eeaj.v9i1.42349.

Bank Indonesia. (2020). Transaksi Kartu Kredit. Bank Indonesia.

Bapat, D. (2020). Antecedents to Responsible Financial Management Behavior Among Young Adults: Moderating Role of Financial Risk Tolerance. International Journal of Bank Marketing, 38(5), 1177-1194. https://doi.org/10.1108/IJBM-10-2019-0356.

Budiono, E. (2020). Analisis Financial Knowledge, Financial Attitude, Income, Locus of Control , Financial Management Behavior Masyarakat Kota Kediri. Ilmu Manajemen, 8(1), 284-295.

Djou, L. G. (2019). Analisis Pengaruh Literasi Keuangan, Sikap Keuangan dan Kepribadian Terhadap Perilaku Pengelolaan Keuangan UMKM di Kabupaten Ende. Jurnal Magisma, 7(2), 123-134. https://doi.org/10.35829/magisma.v7i2.57.

Herdjiono, I., \& Damanik, L. A. (2016). Pengaruh Financial Attitude,Financial Knowledge, Parental Income Terhadap Financial Management Behavior. Jurnal Manajemen Teori Dan Terapan/ Journal of Theory and Applied Management, 9(3), 226-241. https://doi.org/10.20473/jmtt.v9i3.3077.

Hidayah, N., \& Bowo, P. A. (2018). Pengaruh Uang Saku, Locus of Control, Dan Lingkungan Teman Sebaya Terhadap Perilaku Konsumtif. Economic Education Analysis Journal, 7(3), 1025-1039. https://doi.org/10.15294/eeaj.v7i3.28337.

Humaira, I., \& Sagoro, E. M. (2018). Pengaruh Pengetahuan Keuangan, Sikap Keuangan, Dan Kepribadian Terhadap Perilaku Manajemen Keuangan Pada Pelaku UMKM Sentra Kerajinan Batik Kabupaten Bantul. Jurnal Nominal, 7(1). https://doi.org/10.21831/nominal.v7i1.19363.

Ida, I., Zaniarti, S., \& Wijaya, G. E. (2020). Financial Literacy, Money Attitude, Dan Financial Management Behavior Generasi Milenial. Jurnal Muara Ilmu Ekonomi Dan Bisnis, 4(2), 406-413. https://doi.org/10.24912/jmieb.v4i2.9144.

Khairani, F., \& Alfarisi, M. F. (2019). Analisis Pengaruh Financial Attitude, Financial Knowledge, Pendidikan Orang Tua Dan Parental Income Terhadap Financial Management Behavior Pada Mahasiswa S1 Universitas Andalas Padang. Jurnal Ilmiah Mahasiswa Ekonomi Manajemen, 4(1), 360-371. https://doi.org/10.24815/jimen.v4i1.10489.

Mardahleni, M. (2020). Pengaruh Pengetahuan Keuangan Dan Kepribadian Terhadap Perilaku Ma Najemen Keuangan (Studi Pada Rumah Tangga Di Nagari Persiapan Anam Koto Utara Kecamatan Kinali Kabupaten Pasaman Barat). Jurnal Apresiasi Ekonomi, 8(3), 511-520. https://doi.org/10.31846/jae.v8i3.297.

Mardhatillah, R. A., Susyanti, J., \& Hufron, M. (2020). Pengaruh Financial Knowledge, Financial Attitude Dan Locus Of Control Terhadap Financial Management Behavior (Studi Kasus Pada Pelaku 
Ekonomi Kreatif Sub Sektor Fashion Kota Kediri). E-Jurnal Riset Manajemen, 9(3).

Muhidia, S. C. U. (2019). Pengaruh Pengetahuan Keuangan, Sikap Keuangan, dan Locus of Control Terhadap Perilaku Keuangan Mahasiswa Prodi Manajemen Universitas Muhammadiyah Gresik. Jurnal Manajerial, 5(2), 58-65. http://dx.doi.org/10.30587/manajerial.v5i2.840.

Ningtyas, M. N. (2019). Literasi Keuangan pada Generasi Milenial. Jurnal Ilmiah Bisnis Dan Ekonomi Asia, 13(1), 20-27. https://doi.org/10.32812/jibeka.v13i1.111.

Otoritas Jasa Keuangan. (2016). Survei Nasional Literasi dan Inklusi Keuangan 2016. In Survey Report. www.ojk.go.id

Otoritas Jasa Keuangan. (2019). Survei Nasional Literasi dan Inklusi Keuangan 2019. In Survey Report. www.ojk.go.id

Pradiningtyas, T. E., \& Lukiastuti, F. (2019). Pengaruh Pengetahuan Keuangan dan Sikap Keuangan terhadap Locus of Control dan Perilaku Pengelolaan Keuangan Mahasiswa Ekonomi. Jurnal Minds: Manajemen, Ide, Dan Inspirasi, 6(1), 96-112. https://doi.org/10.24252/minds.v6i1.9274.

Putri, S. F., Widodo, J., \& Martono, S. (2016). Pengaruh Literasi Keuangan Melalui Rasionalitas Terhadap Perilaku Konsumtif (Studi Kasus Siswa Kelas XI Ilmu Sosial SMA Negeri se-Kota Semarang). Journal of Economic Education, 5(2), 179-192.

Qurotaa'yun, Z., \& Krisnawati, A. (2019). Pengaruh Literasi Keuangan Terhadap Perilaku Konsumtif Generasi Milenial Di Kota Bandung. JAF- Journal of Accounting and Finance, 3(1), 46-53. https://doi.org/10.25124/jaf.v3i1.2167.

Rizkiawati, N. L., \& Asandimitra, N. (2018). Pengaruh Demografi, Financial Knowledge, Financial Attitude, Locus of Control Dan Financial Self-Efficacy Terhadap Financial Management Behavior Masyarakat Surabaya. Jurnal Ilmu Manajemen (JIM), 6(3).

Rumbianingrum, W., \& Wijangka, C. (2018). Pengaruh Literasi Keuangan Terhadap Pengelolaan Keuangan UMKM. Jurnal Manajemen Dan Bisnis (ALMANA), 2(3), 155-165.

Saepuloh, A., \& Sukaris, S. (2019). Peran Mediasi Locus of Control pada Perilaku Keuangan. Jurnal Manajerial, 6(2), 94-100. https://doi.org/10.30587/manajerial.v6i2.1045.

Setyawan, W., \& Wulandari, S. (2020). Peran Sikap Keuangan dalam Mengintervensi Pengaruh Literasi Keuangan Terhadap Perilaku Manajemen Keuangan Pekerja di Cikarang. Jurnal Sekuritas (Saham, Ekonomi, Keuangan, Dan Investasi), 4(1), 15-23. http://dx.doi.org/10.32493/skt.v4i1.6435.

Shinta, R. E., \& Lestari, W. (2019). Pengaruh Financial Knowledge, Lifestyle Pattern pada Perilaku Manajemen Keuangan Wanita Karir dengan Locus of Control sebagai Variabel Moderasi. Journal of Business \& Banking, 8(2), 271-283. https://doi.org/10.14414/jbb.v8i2.1524.

Susiana, R. (2018). BUDAYA PESISIR: Perilaku Konsumtif Masyarakat Tambaklorok, Kelurahan Tanjung Mas, Kecamatan Semarang Utara, Kota Semarang. Sabda: Jurnal Kajian Kebudayaan, 13(1). https://doi.org/10.14710/sabda.13.1.59-66.

Suwatno, Waspada, I. P., \& Mulyani, H. (2019). Meningkatkan Perilaku Pengelolaan Keuangan Mahasiswa Melalui Financial Literacy Dan Financial Sel Efficacy. JPAK: Jurnal Pendidikan Akuntansi Dan Keuangan, 8(1), 87-96. https://doi.org/10.17509/jpak.v8i1.21938.

Tempo.co. (2019, November 8). Survei OJK: Literasi Keuangan 2019 Meningkat, Tembus 76,19 Persen Bisnis Tempo.co. https://bisnis.tempo.co/read/1269759/survei-ojk-literasi-keuangan-2019meningkat-tembus-7619-persen.

Udayanthi, N. O., Herawati, N. T., \& Julianto, I. P. (2018). Pengaruh Literasi Keuangan, Kualitas Pembelajaran dan Pengendalian Diri Terhadap Perilaku Konsumtif (Studi Empiris pada Mahasiswa Jurusan Akuntansi Program S1 Universitas Pendidikan Ganesha). JIMAT (Jurnal Ilmiah Mahasiswa Akuntansi), 9(2), 195-208. http://dx.doi.org/10.23887/jimat.v9i2.20502.

UGM. (2017). Inflasi dan Indeks Harga Konsumen - Macroeconomic Dashboard. https://macroeconomicdashboard.feb.ugm.ac.id/inflasi-dan-indeks-harga-konsumen/.

Wibowo, C. S., \& Athanasius, S. S. (2019). Faktor Yang Mempengaruhi Keputusan Konsumen Menggunakan Kartu Kredit di Mall Semarang. JEMAP : Jurnal Ekonomi, Manajemen, Akuntansi Dan Perpajakan, 2(1), 76-92. https://doi.org/10.24167/jemap.v2i1.2100.

Wicaksono, A. B., \& Nuryana, I. (2020). Pengaruh Sikap Keuangan, Teman Sebaya, dan Kecerdasan Spiritual Melalui Kontrol Diri Terhadap Perilaku Pengelolaan Keuangan. Economic Education Analysis Journal, 9(3), 940-958. https://doi.org/10.15294/eeaj.v9i3.42352.

Wijaya, I., \& Yanuar. (2021). Pengaruh Financial Knowledge, Financial Satisfaction, Financial Confidence Terhadap Financial Behavior. Jurnal Manajemen Bisnis Dan Kewirausahaan, Vol.5, No.1., 5(1), $72-$ 76. https://doi.org/10.24912/jmbk.v5i1.10832. 